American Journal of Biochemistry and Biotechnology 4 (4): 354-366, 2008

ISSN 1553-3468

(C) 2008 Science Publications

\title{
Perspectives of Solid State Fermentation for Production of Food Enzymes
}

\author{
${ }^{1}$ Cristobal Noe Aguilar, ${ }^{2}$ Gerardo Gutiérrez-Sánchez, ${ }^{3}$ PLilia A. rado-Barragán, ${ }^{1}$ Raul Rodríguez-Herrera. \\ ${ }^{1}$ José L. Martínez-Hernandez and ${ }^{1}$ Juan C. Contreras-Esquivel \\ ${ }^{1}$ Department of Food Research, Universidad Autónoma de Coahuila, 25280, Saltillo, Coahuila Mexico \\ ${ }^{2}$ Complex Carbohydrate Research Center, The University of Georgia, Athens, GA, USA \\ ${ }^{3}$ Biotechnology Department, Universidad Autónoma Metropolitana, \\ Iztapalapa, O9340, Mexico, D.F.
}

\begin{abstract}
Food industry represents one of the economic sectors where microbial metabolites have found a wide variety of applications. This is the case of some enzymes, such as amylases, cellulases, pectinases and proteases which have played a very important role as food additives. Most of these enzymes have been produced by submerged cultures at industrial level. Many works in the literature present detailed aspects involved with those enzymes and their importance in the food industry. However, the production and application studies of those enzymes produced by solid state fermentations are scarce in comparison with submerged fermentation. This review involves production aspects of the seven enzymes: tannases, pectinases, caffeinases, mannanases, phytases, xylanases and proteases, which can be produced by solid state fermentation showing attractive advantages. Additionally, process characteristics of solid state fermentation are considered.
\end{abstract}

Key words: Food enzymes, production, solid state culture

\section{INTRODUCTION}

Employment of enzymes in food industry is based on three basic aspects: i) the control of quality of certain foods, ii) the modification of the properties of some food additives and of the foods itself and, iii) the production of enzymes used as food additives. In the first case, presence or absence of some enzymatic activities has a great impact in the quality of the final product. Examples are: Alkaline-phosphatase as evaluation of the effectiveness of the process of milk pasteurization; the catalase is an index of microbial contamination in certain foods, the activation in situ of the pectinesterase allows to obtain firmer fruits and vegetables with more attractive sensorial attributes for the consumers ${ }^{[1,2]}$, the peroxidase and the lipoxigenase are used to evaluate the efficiency of the blanching process of some vegetables ${ }^{[3]}$. Baduí ${ }^{[4]}$ mentioned that presence of some other enzymes have been proposed to be used in the control of quality of the foods, such it is the case of the invertase in the beer pasteurization; the amylase like index of excessive heating in honeys, the esterases are an index of fungal contamination, the Nacetyl- $\alpha$-D-deshydrogenase for the destruction of Salmonella in pasteurized eggs and the deshydrogenase for the microbial contamination of the milk. It is important to consider that to evaluate the quality of foods, some analytical methods are based in enzymatic reactions, such is the case of the soluble sugar content analysis, which is executed in units that possess such enzymes in electrodes or absorbed in membranes (enzymatic biosensors). The enzymatic reaction usually liberates a product, which is then related to the concentration of initial substrate provided by the analyzed sample.

The second aspect refers to the use of enzymes to modify the physico-chemical and reological properties of the foods, such as amylases, lipases and pectinases. The enzymes used as biocatalysts for the production of some aminoacids can also be considered as an example of this particular aspect ${ }^{[5]}$. These last aspects, involve production processes of enzymes, which have applications in the food industry. The processes include the extraction of enzymes from agroindustrial and fishing wastes, vegetable and animal tissues and microbial sources. The latter being one of the most important production systems in the food industry, due to the fact of enzymes are obtained in shorter times without chemical compounds production that then can represent potential problems like environmental contamination and health; they also possess very homogeneous characteristics.

Corresponding Author: Cristobal Noe Aguilar, Food Research Department, School of Chemistry, Universidad Autónoma de Coahuila, Saltillo, 25280, Coahuila, México 
At industrial level, enzyme production is a growing field of biotechnology. Annual world sales figures are close to $10^{9}$ dollars with increasing numbers of patents and research articles related to this field ${ }^{[6]}$. Most enzyme manufacturers produce enzymes using submerged fermentation (SmF) or liquid surface (SLF) fermentation techniques with enzyme titers in the rage of grams per liter ${ }^{[7]}$. Such levels are a prerequisite if specific compounds are to be considered as commodities because product recovery costs are inversely proportional to concentration in a fermentation broth. There is however a significant interest in using solid-state fermentation (SSF) techniques to produce a wide variety of enzymes, mainly from mold origin, as indicated by the growing number of research papers in the literature and the marketing and development by a small but visible number of fermentation industries ${ }^{[6]}$. Among the advantages for SSF processes it is often cited that enzyme titers are higher than in $\mathrm{SmF}$, when comparing the same strain and fermentation broth. However, there is a scarcity regarding physiological studies comparing SSF and SmF when trying to explain why microorganisms produce higher titers in the first kind of process as compared to the second. This lack of information makes difficult any assessment regarding the value of one process versus the other thereby hindering the fundamental approach to process optimization and design for SSF technique in areas such as strain improvement, solid substrate engineering and process control.

Some of the better known examples are the amylases $^{[8-11]} \quad$ Glucoamylases $^{[9,11]}$, cellulases ${ }^{[10,11]}$, pectinases $^{[12-16]}$, caffeinases, lipases ${ }^{[18,19]}$ and proteases production $^{[20,21]}$.

Considering the contributions mentioned previously, in this work the generalities of the SSF process are reviewed and the catalytic characteristics and some of the advances achieved in the production of six enzymes with potential application in the food industry for SSF are presented.

\section{MATERIALS AND METHODS}

Solid State Fermentation (SSF): Term solid state fermentation (SSF) is applied for the processes in which insoluble materials in water are used for the microbial growth $^{[22]}$, In the fermentative processes of this type, the quantity of water should not exceed the capacity of saturation of the solid bed in which the microorganisms grow $^{[23]}$. Water is essential for the microbial growth and in SSF and it is present in thin layers and in occasions, absorbed inside the substrates ${ }^{[24]}$.
In the western world the SSF has been fewer studied that the SmF and SLF. The most important differences among these systems are the relatively low content of humidity in the means, the formation of gradients of temperature, nutrients and products and also, sporulation mechanisms as well as the production of enzymes and secondary metabolites as the rifamycin $^{[25]}$, $\operatorname{citric~acid}^{[26]}$ and aromas ${ }^{[27]}$.

Substrates from agricultural or industrial wastes (wheat straw or barley, sugar cane bagasse, coffee pulp, grape wastes, copra pasta, among other) or inert materials (as resins of ionic exchange, acreolite or poliurethane foam) can be used. The pretreatments of these materials is really few, generally a milled previous and wash. Of these characteristics some advantages and disadvantages of the SSF in comparison to the $\mathrm{SmF}$ are derived and presented next ${ }^{[28]}$.

\section{Advantages:}

- The culture media are simple. Some substrates can be used direclty as a solid media or enriched with nutrients

- The product of interest is concentrated, that which facilitates its purification

- The used inoculum is the natural flora of the substrates, spores or cells

- The low humidity content and the great inoculum used in a SSF reduce vaslty the possibility of a microbial contamination

- The quantity of waste generated is smaller than the $\mathrm{SmF}$

- The enzymes are low sensive to catabolic repression or induction ${ }^{[29]}$

\section{Disadvantages:}

- The used microorganisms are limited those that grow in reduced levels of humidity

- The determination of parameters such as humidity, $\mathrm{pH}$, free oxygen and dioxide of carbon, constitute a problem due to the lack of monitoring devices

- The scale up of SSF processes has been little studied and it presents several problems

Some authors have described the types of bioreactors more used in $\mathrm{SSF}^{[30]}$. The used simpler bioreactors are the trays that consist on placing fine layers of solid substrate $5-10 \mathrm{~cm}$ on a horizontal area, the air flux in these trays is not forced through the substrate tray but if around the trays and frecuently the temperature is controlled in a room. The following type 
in complexity is the bio-rector of packed channel, which is characterized to have the static substrate on a plate perforated through the one which a current of air is drived. The typical design of these reactors consists on a cylinder of stainless steel that it can have a better control of temperature and humidity when a wet air is provided. Both systems are static.

The dynamic bio-rectors used in SSF can rotational or upset drum being. The first one consist on an inclined cylinder or horizontal with or without agitation that it is rotated on their axial axis to increase the air flux in the channel. The second one presents a configuration different to the first one, possesing palette or helical agitators to move the channel and sometimes, an air flux is forced through the packing. In the dynamic bio-reactors the agitation can be intermittent or continue, but this factor represents some disadvantages for some processes like damage in fungal structures. Furthemore, the control of the temperature gets complicated.

\section{RESULTS}

Production of Enzymes by SSF: In studies where the enzyme concentration obtained from SmF, SLF and SSF have been compared, it has been observed that in SSF the titles are higher and also, the produced enzymes are stable to wider ranges of temperature and $\mathrm{pH}$. This has been evidenced for enzymes such as the amylase $^{[31]}$, pectinase $e^{[14,15]}$, tannase ${ }^{[32]}$ and protease ${ }^{[21]}$. In these studies it has demonstrated that SSF presents attractive advantages for the production of microbial enzymes. More recent studies in SSF involve the production of enzymes with potential utilization in the food industry. Such enzymes are a) tannin acyl hydrolase, b) protopectinase, c) caffeinase, d) mannanase, e) phytase, f) xylanase and g) protease, on those which next some of the most important characteristics are revised, including the reaction that catalyze and the possible industrial applications.

Tannase: Tannase or tanin acyl hydrolase (EC, 3.1.1.20) catalyzes the hydrolysis reaction of the ester bonds present in the hydrolizable tannins and gallic acid esters. Its industrial production is only by a microbial way using $\mathrm{SmF}$, where the enzymes are mainly produced intracellularly, implying additional costs in its manufacture ${ }^{[33]}$. Recently, tannase is commercialized by Biocon (India), Kikkoman (Japan) ASA Specilaeznyme GmbH (Germany) and JFC GmbH (Germany) with different catalytic units depending of the product presentation. However several studies have reported interesting advantages between the tannase produced by SSF in comparison with that produced by
$\mathrm{SmF}^{[7,28,32,34-38]}$. In these works, attractive advantages are indicated, such as the high enzymatic production (up to 5.5 times more than in SmF), the nature extracellular of the enzymes and the stability to wide $\mathrm{pH}$ and temperature ranges ${ }^{[32,33]}$ reported a tannase productivity of 6.667 and 1.275 UE/Lh for SSF and $\mathrm{SmF}$ respectively and a maximum of intracellular and extracellular tannase activity respectively 18 and 2.5 times higher in SSF that in SmF.

At the moment, the biggest commercial applications of tannases are in the manufacture of instantaneous tea or of acorn liquor and in the gallic acid production ${ }^{[39-41]}$, which is used as an important intermediary compound in the food and pharmaceutical industry, respectively for the synthesis of propylgallate and trimethoprim ${ }^{[42]}$. Also, the tannase is used as clarifying agent in some wines, juices of fruits and in refreshing drinks with a coffee flavor ${ }^{[43]}$.

In the case of the wines, it is important to state that the main tannins present are catechins and epicatechins, which can get a complex with galactocatechins and others galloyl-derivated. The amount of catequin in white wines is around of $10-50 \mathrm{mg} \mathrm{L}^{-1}$, while in other wines it can reach $800 \mathrm{mg} \mathrm{L}^{-1[44]}$. Fifty percent of the wine color is due to the presence of tannins, however, if these compounds are oxidized to quinones by contact with the air, an undesirable turbidity could be formed, affecting the wine quality. The use of tannases can solve this problem.

Tannins are present in low quantitites in beer, especially as anthocianins. However, when beer proteins are present in high quantities, an undesirable turbidity is presented by complexing with these tannins. This problem could be solved with the employment of tannases.

The tannery effluents contain high amounts of tannins, mainly polyphenols, which are dangerous pollutants, for this reason the use of the tannase represents an inexpensive and effective treatment for the removal of these compounds.

Pectinases: Most of pectic-polymers are comprised of smooth homogalacturonan and ramified hairy regions. Smooth regions consist of a linear homogalacturonan backbone, while hairy regions consist of rhamnogalacturonan backbone with side-branches of varying length ${ }^{[45]}$. Detailed information on elaborate models on pectin structure can be found in some reviews ${ }^{[46,47]}$. Traditional breaking down of pectic substances was through the use of well-know pectic enzymes (pectinesterase, polygalacturonase and pectin lyase) able to degrade only the smooth region. Recently, several new enzymes have been reported 
which degrade parts of hairy region such as rhamnogalacturonan hydrolase, rhamnogalacturonan lyase and xylogalacturonase, ${ }^{[45]}$. Properties and characteristics of common and new pectic enzymes are discussed by Contreras-Esquivel et $a l^{[47]}$ and Aguilar et al. ${ }^{[48]}$.

Common pectinolytic enzymes products have been commerciallized for more than two decades ${ }^{[49]}$ and can be produced either by $\mathrm{SmF}$ and $\mathrm{SSF}^{[50,51]}$. Production of common pectic enzymes from Aspergillus niger and others fungi has been reported in solid state cultures employing agricultural by-products such as: cassava fibrous waste ${ }^{[52]}$, wheat bran $^{[53]}$, apple pomace ${ }^{[54-56]}$, corn barn ${ }^{[57]}$, citrus wastes ${ }^{[15,58-60]}$, coffee pulp ${ }^{[15]}$, sugar cane baggase ${ }^{[14,61-63]}$ and raw starch from cassava tuber. SSF represents an interesting alternative for the production of mould pectic enzymes, because these enzymes are synthetized in a high concentration ${ }^{[64]}$.

The pectinolytic fungal enzymes are of commercial interest to the food, textil, pulp and paper and wastewater treatment areas ${ }^{[65]}$. In food technology, pectic enzymes are industrially employed in the extraction, clarification and concentration of fruit juices, in the clarification of wines, in the extraction of oils, flavours and pigments from plant materials. Furthermore, pectic enzymes have been employed for carried out extraction and modification of pectin chain. Great amounts of agroindustrial wastes rich in polysaccharides, such as pectic substances are produced at worldwide. Some of these wastes are used for the production of pectin. Purified pectinolytic enzymes have been proposed for extracting and modifying of pectin. Currently, pectin is extracted at industrial scale by physicochemical methods, but lately new biotechnological (microbial and enzymatic) alternatives are being developed.

Caffeinases: Among the enzymes presented in this rewiew, the caffeinases are the less studied. These enzymes are methyl-releasing from caffeine molecule to give teophilline and methanol as products, then teophilline is transformed in 3-methylxantine and xantine. Some metabolic studies have been carried out in humans, bacteria and filamentous fungi ${ }^{[18]}$ trying to elucidate the biodegadation pathway of caffeine.

Caffeine is an alkaloid contained in some beverages, fruits and agroindustrial wastes. The presence of caffeine in agroindustrial wastes represents a limitant for its use as animal feed. Several attempts have been made to eliminate this molecule from foods and feeds, but the results have been poors.

Hakil et al. ${ }^{[17]}$ studied the ability of Aspergillus tamarii V12A25 to use caffeine as sole nitrogen source in solid state fermentation (SSF) using two different supports, polyurethane foam (PUF) and sugarcane bagasse. Results in this study demonstrated that caffeine can be used in SSF as sole nitrogen source if sucrose is used as the carbon source. If a simpler nitrogen source (ammonium sulfate, urea) is added to the medium containing caffeine, this $\mathrm{N}$-source will repress the caffeine consumption. If saccharose is still present when the simple nitrogen source has been degraded, caffeine will be used as $\mathrm{N}$-source. Caffeine at a concentration of $8 \mathrm{~g} \mathrm{~L}^{-1}$ has not effect the fungal growth when a simple $\mathrm{N}$-source is present in the solid medium. The main difference between the two solids used as supports in SSF was the required time to complete the fermentation. With sugarcane bagasse as support, substrates in the impregnated medium were degraded ca 1.6 times faster than with PUF as support. Theophylline, the major product from caffeine degradation was completed. However, the major advantage of using PUF as a support, over sugar cane bagasse, is the possibility to determinate the fungal biomass.

The literature about this enzymes is still scarse, but is very attractive the ability of certain fungal strains to degradate the caffeine, which could be used to minimize the concentration of this molecule in foods and feeds.

Mannanases: $\quad \beta$-D-mannanases are hydrolytic enzymes, which act on hemicellulose chains (called mannans) whose composition and structure chemistry is formed by units of D-manose. It is important to clarify that xylan is another type of hemicellulose composed by monomeric units of the D-xilose. Also, it should be remembered that the hemicellulose is not a homopolymer, consequently its chemical structure not is formed by only type of sugar, but rather its monomeric units are two to four different residuals of sugar forming a heteropolysaccharide ${ }^{[66]}$. In this context, this review will refer as substrate for the mananases to that hemicellulose type with a composition of D-manose.

The mannanases or (1-4)-D-mannanmanohydrolases are those enzymes that produce oligosaccharides through the hydrolysis of the connections ( $\beta 1-4)$-D-manopyranosil into hemicellulose chains. Most of the mannanase production studies involve microbial $\mathrm{SmF}$, but it is known that this enzyme can be extracted from crustaceans, leguminous seeds; and some spineless ${ }^{[67]}$.

Microbial production, purification and characterization of mannanases have been studied in SmF using microorganisms such as Escherichia coli ${ }^{[68]}$, 
Bacillus pulmilus ${ }^{[69]}$, Thielvia terrestris ${ }^{[70]}$, Trichoderma harzianum ${ }^{[71]}$, Pseudomonas sp. P.T.5 ${ }^{[72]}$, Caldocellum saccarolyticus ${ }^{[76]}, \quad T$. reesei $\mathrm{C}-30^{[73]}$, Bacillus sp. KK01 ${ }^{[74]}$. Venegas et al. ${ }^{[75]}$ demonstrated that mannanases from $A$. oryzae and $A$. niger can be produced in SSF using coffee pulp and coconut copra cake as solid substrates. The produced mannanases were also extracted, purified and characterized. These results confirmed that SSF is a highly attractive process for mannanase production using agroindustrial byproducts.

The mannanase production at industrial level is still limited, but it is known that these are being used in the bleached of the paper pulp diminishing the use of chlorine until in $25 \%{ }^{[76]}$ and they can be applied in the instantaneous coffee manufacture to reduce the viscosity of the extract during the extraction process ${ }^{[72]}$.

Phytases: Phytase (EC, 3.1.1.8) is a phosphomonoesterase that hydolyses phytic acid and several phosphoesters contained in foods, such as wheat, canola oil and mung beans. The products of the hydrolysis reaction of phyitic acid are inositol and phosphoric acid. Microbial phytases are of interest for biotechnological applications, especially for the phytate reduction in foods and feedstuffs. Some attempts for industrial phytase production in SSF have been carried out. However, the SmF system is the main process used for the production of this enzime.

Phytase production by Aspergillus carbonarius in SSF using canola oil as substrate, was studied by AlAsheh and Duvnjak ${ }^{[78]}$. They showed that phytase production of was associated with fungal growth, reaching a maximum activity after $72 \mathrm{~h}$ of culture.

By other hand, Ebune et al. ${ }^{[79]}$ reported that phosphate concentration influenced phytase production of A. ficuun in a solid state fermentation process. Lower concentrations of this compound favoured the enzyme production. Addition of Tween 80 and sodium oleate increased the rate of phytase production and hydrolysis of phytic acid, while the Triton X-100 addition had a negative effect on these microbial processes. Glucose concentrations of up to $5.2 \%$ increased the biomass formation, production of phytase and the rate of phytic acid hydrolysis, while glucose concentgrations higher than $9.8 \%$ had an adverse effect on these processes.

Xylanases: Xylanases are a complex system of enzymes required to complete degradation of xylan, a heterogeneous polysaccharide. Endoxylanases hydrolise the xylose chains of xylan, while the different lateral groups of the molecule are hydrolyzed by a mixture of acetylesterases, arabinofuranosidases, glucuronidases and other esterases.

In the nature, some microorganisms metabolize several energy sources due to the capacity to produce different xylanase classes, besides the degradation of the cellular wall of the plants in coordination with other hidrolases permits the colonization processes. These microbial xylanases have found biotechnological applications in the paper and food industries, as well as in the treatment of solid residuals ${ }^{[80]}$. When xylanases are free of cellulases, these preparations are used for the bleaching treatment of the pulp in the production and recycling of the paper. This application brings environmental implications of relevance; since it is avoided or it diminishes the use of toxic compounds during these processes without alter the quality of the paper obtained. The use of xylanases of microbial origin has substituted the use of chlorine-compounds in these processes ${ }^{[81,82]}$.

Join with other hemicellulases, the xylanases allows the obtaining of oligosaccharides from xylans (from agricultural wastes) which can be used as food additives and edulcorants ${ }^{[83]}$. Also, xylanases and cellulases are used for the texture modification of bakery masses and also, for the improvement of the diets of corral birds, since the enzymatic hydrolysis of arabinoxylans (of forages and cereals) increases the nutritious efficiency of the diet.

Commercial xylanases preparations are obtained from different microorganisms and diverse culture systems, which are applied according to the desired enzymatic profile. New fungal xylanases have interesting properties such as thermal, electrostatic, $\mathrm{pH}$ and catalytic stabilities ${ }^{[84,85-87]}$.

These new enzymes have been produced by SSF process due to it offers an alternative that is worthwhile to study with more detail, to produce isoenzymes with the mentioned properties. Likewise, it should be considered the study of the xylanases expression in strains obtained from parasexual cross where it is carried out the genetic recombination for the obtaining of new strains with characteristics highlighted in the levels and in the xylanase productivity ${ }^{[88]}$.

Proteases: Proteases have an important position in the enzyme industry as they have a determinant role in the microbial and human physiological needs as well as the great commercial market applications. Since they are indispensable for living organisms, proteases occur in a wide diversity of plants, animals and microorganisms ${ }^{[89]}$. Papain, bromelain, keratinases and ficsin represent some of the plant proteases ${ }^{[90]}$; however, the use of plants as a source of proteases is 
governed by factors no easily controlled such as land availability and climatic conditions as well as its excretation is a time-consuming process. Pancreatic, trypsin, chymotrypsin, pepsin and rennin are the most important proteases of animal origin. However, their production depends on the availability of livestock for slaughter ${ }^{[91]}$. Therefore microbial proteases are preferred above enzymes from plant and animal sources since they present most of the desired characteristics for biotechnological applications $^{[92]}$.

In early days, proteases were classified according to their source (animal, plant or microbial), catalytic action (endo or exopeptidases), the molecular size, charge or substrate specificity, however a more rational system is now based on a comparison of active sites, mechanisms of action and three-dimentional structure. Four mechanistic classes are recognized by the International Union of Biochemistry and within these classes, six families of proteases are recognized to date: serine proteases (EC 3.4.21), serine carboxy proteases (EC 3.4.16), cystein proteases (EC 3.4.22), aspartic proteases (EC 3.4.23), metallo proteases I (EC 3.4.24) and metallo carboxy proteases (EC 3.4.17) ${ }^{[93]}$.

Proteases are by far the most important enzymes in the food industry used in food proteins modification. Proteases have been used in ancient technology to improve palatability and storage stability of the available protein sources; consequently, proteases have a long history of applications in food products and they are used in baked goods, brewing, cereals, cheese, chocolate/cocoa, egg products, meat and fish, wine, protein hydrolysates, antinutrient factors removal. Also they are widely used in the detergent, pharmaceutical, clinical diagnostic, leather, cosmetics and fine chemical industries ${ }^{[94,95]}$.

Then it is not surprising that protease market represents the $60 \%$ of the worldwide sale of enzymes. However, the vast diversity of proteases produced in contrast to the specificity of their action, has attracted great attention in attempts to exploit their physiological and biotechnological applications ${ }^{[96]}$. Most commercial bacterial proteases are mainly actives at neutral and alkaline $\mathrm{pH}$ and are produced by organisms of the genus Bacillus and to lesser extent by Clostridium ${ }^{[97]}$. In general, neutral proteases are active in a narrow $\mathrm{pH}$ range $(\mathrm{pH} \mathrm{5-8)}$ and have relative low thermotolerance. Some of the neutral proteases belong to the matalloprotease type and require divalent metal for the activity while others such as the serine proteases are not affected by chelanting agents. Bacterial alkaline proteases are characterized by their high activity at alkaline $\mathrm{pH}$ and their broad substrate specificity and showing optimal temperatures around $60^{\circ} \mathrm{C}$. These properties make bacterial proteases most advantageous for the detergent and leather industry ${ }^{[98-102]}$. Also, alkaline proteases from Brevibacyterium linens have been used in the dairy industry and proteases from Bacillus thermoprotelyticus are used for the enzymatic synthesis of aspartame.

There is a long list of bacterial proteases commonly used in the food industry and they are mostly produced by submerged fermentation, however fungal protease production is an attractive source for proteases. Fungi can elaborate a wider variety of enzymes than bacteria and a clear example of this statement are the acid, neutral and alkaline proteases produced by Aspergillus niger. The fungal proteases are active over a wide $\mathrm{pH}$ range (4-11) and exhibit board substrate specificity. Fungal enzymes are actually produced by solid state fermentation (SSF) and the advantages of fungal enzyme production in SSF over submerged state fermentation (SmF) system have been extensively discussed by ViniegraGonzález, et al. ${ }^{[6,103]}$.

Fungal acid proteases have an optimal $\mathrm{pH}$ rang from 4-4.5 and they can be stable at $\mathrm{pH}$ values from 2.5-6.0. In general, fungal neutral proteases are metalloproteases inhibited by chellating agents, however they can supplement the action of plant, animal and bacterial proteases reducing bitterness in food protein hydrolysates and food protein modifications. Currently, most detergent proteases are produced by Bacillus strains however, fungal alkaline proteases are advantageous due to the ease downstream processing, moreover an alkaline protease from Conidiobolus coronatus was found to be similar to the ones contained on Indian detergents ${ }^{[104]}$ retaining $43 \%$ of its activity at $50^{\circ} \mathrm{C}$ for $50 \mathrm{~min}$ in the presence of $\mathrm{Ca}^{2+}$ and glycine ${ }^{[105]}$.

In the cheesemaking industry, chymosin is preferred due to its high specificity for casein, which is responsable for its excellent performance in cheesmaking. However, extensive research has been done and it has resulted in the fungal enzymes production by Mucor michei (GRAS) ${ }^{[106]}$ which together with other bacterial enzymes such as those obtained from Bacillus subtillis are gradually replacing chymosin in cheesemaking as these enzymes have higher thermorestistance than animal rennins and chemical treatment of oxidating agents applied to renin obtained from Mucor michei allow to obtain an enzyme with properties similar to those obtained from animals, in terms of productivity and quality of the final product. Moreover, the narrow $\mathrm{pH}$ and temperature specificity are other particularities which make fungal proteases suitable in the cheese make industry. Also, in the milk 
industry acid, alkaline and neutral fungal proteases produced by Aspergillus oryzae have been also used $^{[107]}$.

In the baking industry, endo- and exoproteinases from Aspergillus oryzae have been used to modify wheat gluten by limited proteolysis such enzymatic treatment reduces the mixing time and increases the volume of the loaf. Also, proteases have been used since ancient times to prepare soy products. In this case, alkaline and neutral fungal proteases play an important role in the processing of soya sauce as well in the hydrolysis of soy proteins to improve functional properties and reduce bitterness.

Proteolytic modifications have several applications in food and pharmacy industry where they can be used in a wide number of products (e.g. nutritional supplements, infant formulas, foaming agents, flavoring agents, etc). In the cosmetical industry, where the main limiting factor for the large scale rapid commercialization of enzymatic depilation has been the high cost of the enzyme production, Malathi and Chakraborty $^{[108]}$ reported the use of alkaline proteases from Aspergillus flavus by SSF as an alternative to the expensive prices represented by $\mathrm{SmF}$. They reported the combined advantages of SSF systems with the high prolific amounts of extracellular proteases produced by the fungal strain.

Other works related to the fungal protease production (SSF) and application have been reported, the fungal strain most frequented used are Aspergillus oryzae ${ }^{[109-115]}$, Rhizopus oligosporum, Aspergillus flavus, Aspergillus niger ${ }^{[20]}$, Ophiostoma piceae and Metarhizium anisopliae ${ }^{[116]}$ and they have been successfully used in the acid, alkaline and neutral protease production.

Presently, in order to overcome the high prices of the industrial proteases specially those used in the food and pharmaceutical industries several works are going on the fungal SSF and the feasibility of the process and its positive implications on the protease production have been showed, however studies on the proteolityc specificity and selected applications are need to be done $^{[117-125]}$

\section{CONCLUSION}

Microbial enzymes are widely used as aid processing in food industries. However, the fields of new industrial and analytical applications are being extended in recent years, making necessary to study more deeply this kind of enzymes. Erroneously, it has been considered that enzymes reviewed in this work have been extensively studied and that do not represent a good model for additional studies. Several reports on the influence of culture conditions on the synthesis of microbial enzymes have been made but there is not yet a comprehensive set of models of enzyme regulation. The effect of different carbon sources has been studied. The optimal concentration of constituents in a medium for the enhanced production of enzymes, have been determined. Effect of initial $\mathrm{pH}$, temperature and air flow rate on enzyme production, were also studied. Many applications in detergents, drugs, feed and food industries have been proposed. Although, a fair amount of work has been done on novel reactors and processes for the production of food enzymes, extensive work is yet to be carried out in several topics related to food enzyme production. For example, intensive work on kinetic studies in fermentors remains yet to be done. Extensive studies are needed for the optimisation of the food enzyme production in solid state fermentation considering that this kind of process provides higher productivity due to high levels of enzyme yields and shorter fermentation times. In submerged cultures the enzyme activity decreases by increased the supplementation of carbon source but not in solid state fermentation. This fact suggests that regulatory phenomenon such as induction-repression or activationinhibition is different in both cultures. On the other hand, it is necessary to carry out efforts to understand the importance of enzymes related to the degradation or modification of their substrates and those food enzymes considered as accessories.

According to the previous section, the following problems require more studies: The production of food enzymes related to the degradation of different substrates. Optimisation of physical parameters such as $\mathrm{pH}$, aereation and agitation in fermentors should be done. In this sense, for the production of food enzymes extensive work on reactor, including kinetics should be done to analyse the whole process.

On the other hand, high concentrations of carbon source inhibit enzyme synthesis in submerged fermentation. This observation strongly supports the need to produce food enzymes by feed batch fermentation with the corresponding optimisation work, It should be stressed that literature on high cell density cultivation for food enzymes is not available. Continuous culturer for production of these enzymes should be studied to develop this mode of operation. The fact that food enzyme production by solid state fermentation is not strongly repressed by carbon sources makes this field an atractive way to produce food enzymes. It should be stressed that literature on high cell density cultivation for food enzyme production is not available. Further studies on design of 
reactors for the production of food enzymes can be attempted. An interesting opportunity is the production by solid state fermentation of these enzymes using genetically modified organisms.

\section{REFERENCES}

1. Chávez, S.Ns., H. De La Garza-Toledo, A. Aguilera-Carbó, J.C. Montañez-Sáenz, J.C. Contreras-Esquivel and C.N. Aguilar, 1998. Effect of not ordinary blanchings on physicochemical and microbiological quality of fried potato strips. Ind. Alimen., 20: 19-22.

2. Aguilera-Carbó, A.F., J.C. Montañez, A. Anzaldúa-Morales, M.L. Reyes, J.C. ContrerasEsquivel and C.N. Aguilar, 1999. Improvement of color and limpness of fried fries potatoes by in situ pectinesterase activation. Eur. Food Res. Technol., 210: 49-52.

3. Aguilar, C.N., A. Aguilera-Carbó, J.C. ContrerasEsquivel, A.R. Vidal and H. De La Garza-Toledo, 1996. Effect of the in situ activation of pectinmethylesterase on changes of color and texture of fried potatoes strips. Iberoam. Applied Biotechnol. CIIDIR, 3: 7-14.

4. Baduí, S., 1996. Chemistry of the Foods. Ed. Mexican Alhambra, México, pp: 281-326.

5. Garza, Y.G., M.G. Rodríguez, C.L. Hernández and J.M. Rodríguez, 2000. Optimization of aspartate ammonia lyase production by Bacillus cereus. J. Ind. Microbiol. Biotechnol., 25: 225-228.

6. Viniegra-González, G., E. Favela-Torres, C.N. Aguilar, S. Romero-Gomez, G. Díaz-Godinez and C. Augur, 2003. Advantages of fungal enzyme production in solid state over liquid systems. Biochem. Eng. J., 13: 157-167.

7. Aguilar, C.N., E. Favela-Torres, G. ViniegraGonzález and C. Augur, 2002. Culture conditions dictate protease and tannase production in submerged and solid-state cultures by Aspergillus niger Aa-20. Applied Biochem. Biotechnol., 102-103: 407-414.

8. Raimbault, M. and Alazardd., 1980. Culture method to study fungal growth in solid fermentation. Eur. J. Applied Microbiol. Biotechnol., 9: 199-209.

9. Soccol, C., J.R. Leon, B. Marin, S. Roussos and M. Raimbault, 1993. Growth kinetics of Rhizopus arrhizus in solid state fermentation of treated cassava. Biotechnology Techniques, 7: 563-568.

10. Raimbault, M., 1998. General and microbiological aspects of solid state fermentation. Electronic. J. Biotechnol., 1: 3-21.
11. Soccol, C., B. Marin, M. Raimbault and J. Lebeault, 1994. Breeding and growth of Rhizopus in raw cassava by solid state fermentation. Applied Microbiol. Biotechnol., 41: 330-336.

12. Favela-Torres, E., S. Huerta, S. Roussos and M. Gutierrez-Rojas, 1989. International Seminar on biotechnology in coffee agroindustry, Roussos, S., R. Licona and M. Gutierrez-Rojas, (Eds.). Jalapa, to See., Mexico, pp: 145-155.

13. Antier, P., A. Minjares, S. Roussos and G. Viniegra-González, 1993. New approach for selecting pectinases producing mutants of Aspergillus niger well adapted to solid state fermentation. Biotechnol. Adv., 11: 429-440.

14. Sólis-Pereíra, S., E. Favela-Torres, G. ViniegraGonzález and M. Gutiérrez-Rojas, 1993. Effects of different coal sources on the synthesis of pectinases by Aspergillus niger in submerged and solid state fermentations. Applied Microbiol. Biotechnol., 39: $36-41$.

15. Maldonado, M.C. and A.M. Strasser Of Saad, 1998. Produciton of pectinesterase and polygalacturonase by Aspergillus niger in submerged and solid state systems. J. Ind. Microbiol. Biotechnol., 20: 34-38.

16. Diaz-Godinez, G., J. Soriano-Santos, C. Augur, G. Viniegra-González, 2001. Exopectinases produced by Aspergillus niger in solid-state and submerged fermentation: A comparative study. J. Ind. Microbiol. Biotechnol., 26: 271-275.

17. Hakil, M., F. Voisinet, G. Viniegra-González and C. Augur, 1999. Caffeine degradation in solid state fermentation by Aspergillus tamarii: Effects of additional nitrogen sources. Process Bioch., 35: 103-109.

18. Gwen Falony, Coca Armas, JulioC. Dustet Mendoza and José L. Martínez Hernández, 2006. Production of extracellular lipase from Aspergillus niger by Solid-State Fermentation. 44: 235-240.

19. Palma, M.B., A.L. Pinto, A.K. Gombert, K.H. Seitz, L.R. Castilho and D.M.G. Freire, 2000. Lipase production by Penicillium restrictum using solid waste of industrial babassu oil production as substrate. Applied Biochem. Biotechnol., 84/86: 1137-1145.

20. Villegas, E., S. Aubague, L. Alcantara, R. Auria and S. Revah, 1993. Solid State Fermentation: Acid protease production in controlled $\mathrm{CO}_{2}$ and $\mathrm{O}_{2}$ environments. Biotechnol. Adv., 11: 387-397. 
21. George, S., V. Raju, V. Subramanian and K. Jayaraman, 1997. Comparative study of protease production in solid substrate fermentation versus submerged fermentation. Bioprocess Eng., 16: 381-382.

22. Moo-Young, M., A. Moreira and R. Tengerdy, 1983. Principles of solid state fermentation. In: Fungal Biotechnology, Smith, J., D. Berry and B. Kristiansen (Eds.). Edward Arnold Publishers, London, pp: 117-144.

23. Laukevics, J.J., A.F. Apsite, U.E. Viesturs and R. Tengerdy, 1984. Solid substrate fermentation of wheat straw to fungal protein. Biotechnol. Bioeng., 26: 1465-1474.

24. Mudgett, R., 1986. Manual of Industrial Microbiology and Biotechnology. Demain, A. and N. Solomon (Eds.). American Society for Microbiology, Washington, AD., pp: 66-83.

25. Mejia, A., J. Barrios-González and G. ViniegraGonzález, 1998. Overproduction of rifamycin B by Amycolatopsis mediterranei and its relationship with the toxic effect of barbital on growth. J. Antibiotics, 51: 58-63.

26. Favela-Tores, E., J. Córdova-López, M. GarcíaRivero and M. Gutierrez-Rojas, 1998. Kinetics of growth of Aspergillus niger during submerged, agar surface and solid state fermentations. Process Biochem., 33: 103-107.

27. Shary-Bagnon, V., P. Lozano, G. SaucedoCastañeda and S. Roussos, 2000. Production of 6-pentyl-a-pyrone by Trichoderma harzianum in liquid and solid state cultures. Process Biochem., 36: 103-109.

28. Hesseltine, C.W., 1977. Solid-state fermentation. Process Biochem., 12: 22-24.

29. Aguilar, C.N., C. Augur, E. Favela-Torres and G. Viniegra-González, 2001. Induction and repression patterns of fungal tannase in solid-state and submerged cultures. Process Biochem., 36: 565-570.

30. Mitchell D.A., 1992. Microbial basis of procedures. In: Solid state cultivation, Doelle, H., D. Mitchell and C. Rolz (Eds.). Elsevier, London.

31. Ramesh, M.V. and B.K. Lonsane, 1991. Ability of to solid state fermentation technique to significantly minimize catabolic repression of (á-amilase production by Bacillus licheniformis M27. Applied Microbiol. Biotechnol., 35: 591-593.

32. Lekha, P.K. and B.K. Lonsane, 1994. Comparative titres, location and properties of tannin acyl hydrolase produced by Aspergillus niger PKL104 in solid-state, liquid surface and submerged fermentations. Proceeding Biochem., 29: 497-503.
33. Chaterjee, R., A. Dutta, R. Banerjee and Y. Bhatacharyya, 1996. Production of tannase by solid state fermentation. Bioproc. Eng., 14: 159-162.

34. Lekha, P.K. and B.K. Lonsane, 1997. Production and application of tannin acyl hydrolase: State of the art. Adv. Applied Microbiol., 44: 215-260.

35. García-Peña, I., E. Favela-Torres and C. Augur, 1999. Partial purification of tanasa taken place by Aspergillus niger in fermentation between solid. In: Advance in purification and application of enzymes in biotechnology, Prado, A., S. Huerta, S. Rodríguez and G. Saucedo, (Eds.). Edition UAMI., Mexico, DF., pp: 247-261.

36. Aguilar, C.N., C. Augur, E. Favela-Torres and G. Viniegra-González, 2001. Production of tannase by Aspergillus niger Aa-20 in submerged and solid-state fermentation: Influence of glucose and tannic acid. J. Ind. Microbiol. Biotechnol., 26: 296-302.

37. Van De Lagemaat, J. and D.L. Pyle, 2001. Solidstate fermentation and bioremediation: Development of a continuous process for the production of fungal tannase. Chemical Eng. J., 84: 115-123.

38. Coggon, P., N. Graham and G. Syerson, 1975. Cold water-soluble firebrand. U.K. Patent $n^{\circ}$ 2610533.

39. Chae, S. and T. Yu, 1983. Experimental it manufactures of acorn wine by fungal tannase. Hanguk Sipkum Kwahakoechi, 15: 326-332.

40. Pourrat H., F. Regerat, A. Pourrat and D. Jean, 1985. Production of gallic acid from hangup tannin by to strain of A. niger. J. Ferment. Technol., 63: 401-403.

41. Sittig, M., 1988. Trimethoprim: Pharmaceutical Manufacturing Encyclopedia. 2nd Edn., Noyes Publication, New Jersey, pp: 1756.

42. Lekha P., M. Ramakrishna and B. Lonsane, 1993. Strategies for isolation of potent culture capable of producing tannin acyl hydrolase in higher titres. Chem. Mikrobiol.Technol. Lebensmitt., 15: 5-10.

43. Ribereau-Gayon, P., 1973. Interpretation chimique de la couleur des vines rouges. Vitis., 12: 119-142.

44. Schols, H.A., J.M. Ros and A.G.J. Voragen, 1998. Lemon albedo cell walls contain dinstinct populations of pectic hairy regions. Carbohydrate Polymer., 37: 159-166.

45. Schols H.A. and A.G.J. Voragen, 1996. Complex pectins: Structure elucidation using enzymes. Proceedings of an international symposium on Pectins and Pectinases, DEC. 3-5, Wageningen, the Netherlands, pp: 990. 
46. Rolin, C., B.U. Nielsen and P.E. Glahn, 1998. Pectin. In: Polysaccharides, Dumitriu and Severian, (Eds.). Dekker Publisher, New York, pp: 377-431.

47. Contreras-Esquivel, J.C., R.A. Hours, C.N. Aguilar, M.L. Reyes-Vega and J. Romero, 1997. Microbial and enzymatic extraction of pectin: A review. Arch. Latinoamer. Nutr., 47: 208-216.

48. Aguilar, C.N., J.C. Contreras-Esquivel, E. FavelaTorres, 2002. Production of pectinase. In: Concise Encyclopedia on Bioresource Technology. Humana Press.

49. Heldt Hansen, H.P., L.V. Kofod, G. Budolfsen, P.M. Nielsen, S. Huttel and Bladt, 1996. Application of tailormade pectinases. Pectins and pectinases: Proceedings of an international symposium, Wageningen, the Netherlands, 3: 463-474.

50. Fogarty, W. and T.C. Kelly, 1983. Pectic enzymes Extraction and clarification of fruit juices and grape musts, citrus fruit juice and wine technology, maceration of vegetables and fruits and in the extraction of olive oil. Microbial enzymes and biotechnology, Fogarty, W.M., (Eds.). Applied Science Publishers, London, pp: 131-182.

51. Sakai, T., T. Sakamoto, J. Hallaert and E.J. Vandamme, 1993. Pectin, pectinase and protopectinase: Production, properties and applications. Adv. Applied Microbiol., 39: 213-294.

52. Budiatman, S. and B.K. Lonsane, 1987. Cassava fibrous waste residue: A substitute to wheat bran in solid state fermentation. Biotechnol. Lett., 9: 597-600.

53. Acuña-Argüelles, M., M. Gutierrez-Rojas, G. Viniegra-González and E. Favela-Torres, 1995. Production and properties of three pectinolytic activites produced by Aspergillus niger by submerged and solid state fermentation. Appl. Microbiol. Biotechnology, 43: 808-814.

54. Ghildyal, N.P., S.V. Ramakrishna, P.N. Devi, B.K. Lonsane and H.N. Asthana, 1981. Large scale production of pectolytic enzyme by solid state fermentation. J. Food Sci. Technol., 18: 248-51.

55. Hours, R.A., C.E. Voget and R.J. Ertola, 1988. Apple pomace as raw material for pectinases production in solid state culture. Biological Wastes, 23: 221-228.

56. Hours, R.A., C.E. Voget and R.J. Ertola, 1988. Some factors affecting pectinase production from apple pomace in solid-state cultures. Biological Wastes., 24: 147-157.

57. Berovic, M. and H. Ostroversnik, 1997. Production of Aspergillus niger pectolytic enzymes by solid state bioprocessing of apple pomace. J. Biotechnol., 53: 47-53.
58. Couri, S. and A.X. Farias, 1995. Genetic manipulation of Aspergillus niger for increased synthesis of pectinolytic enzymes. Rev. Microbiol., 26: 314-317.

59. Maldonado, M.C., A. Navarro and D.A.S. Callieri, 1986. Production of pectinases by Aspergillus sp. using differently pretreated lemon peel as the carbon source. Biotechnol. Lett., 8: 501-504.

60. Siessere V., Said S., 1989. Pectic enzymes production in solid-state fermentation using citrus pulp pellets by Talaromyces flavus, Tubercularia vulgaris and Penicillium charlessi. Biotechnol. Lett., 11: 343-344.

61. Garzon, C.G. and R.A. Hours, 1992. Citrus waste: An alternative substrate for pectinase production in solid-state culture. Bioresource Technol., 39: 93-95.

62. Acuña-Argüelles, M., M. Gutierrez-Rojas, G. Viniegra-González and E. Favela-Torres, 1994. Effect of water activity on exo-pectinase production by Aspergillus niger $\mathrm{CH}_{4}$ on soild state fermentation. Biotechnol. Let., 16: 23-28.

63. Huerta, S., E. Favela, R. López-Ulibarri, A. Fonseca, G. Viniegra-González and M. Gutiérrez-Rojas, 1994. Absorbed substrate fermentation for pectinase production with Aspergillus niger. Biotechnol. Tech., 8: 837-842.

64. Solís-Pereira, S., E. Favela-Torres, M. Gutierrez-Rojas, S. Roussos, G. SaucedoCastañeda, R. Gunasekaran and G. ViniegraGonzález, 1996. Production of pectinases by Aspergillus niger in solid state fermentation at high initial glucose concentrations. World J. Microbiol. Biotechnol., 12: 257-260.

65. Castilho, I.R., T.L.M. Alves and R.A. Medronho, 1999. Recovery of pectolytic enzymes produced by solid state culture of Aspergillus niger. Process Biochem., 34: 181-186.

66. Gillespie, A.M., K. Cook and M.P. Coughlan, 1990. Characterization of an endopolygalacturonase produced by solid-state cultures of the aerobic fungus Penicillium capsulatum. J. Biotechnol., 13: 279-292.

67. Dekker, R. and G. Richards, 1976. Hemicellulases: Their ocurrence purification, properties and mode of action. Adv. Carbohydrates Chem. Biochem., 32: 277-352.

68. Bug, P., T. Clark, M. Mackie, M. Hugh and R. Daniel, 1991. The characterisation of to thermostable endo-1,4 - $\beta$-mannanase cloned from Caldocellum saccarolyticus. Applied Microbiol. Biotechnol., 131: 333-336.

69. Akino, T., C. Kato and K. Horikoshi, 1989. Two Bacillus $\beta$-mannanases having different $\mathrm{COOH}$ termini plow produced in Escherichia coli carring pMAH5. Applied Environ. Microbiol., 55: 3158-3183. 
70. Araujo, A. and O. Ward, 1990. Mannanase components from Bacillus pulmilus. Applied Environ. Microbio., 1954-1956.

71. Araujo, A. and O. Ward, 1990b. Purification and some properties of the mannanases from Thielavia terrestris. J. Ind. Microbiol, 6: 269-274.

72. Torrie, J.P. and D.J. Senoir, 1990. Production of mannanase by Trichoderma harzanium E58. Applied Microb. Biotechnol., 34: 303-307.

73. Yamura, Y., T. Matsumoto, M. Funatsu and Y. Funatsu, 1990. Purification and some properties of endo-1,4- $\beta$-mannanase from Pseudomonas sp. P.T - 5. Agric. Biol. Chem., 54: 2425-2427.

74. Arisan Atac, Y., R. Hodits, D. Kristufek and C. Kubicek, 1993. Purification and characterization of $\beta$-mannanase of Trichoderma reesei C-30. Applied Microbiol. Technol., 39: 158-165.

75. Hossain, M.Z., J. Abe and S. Hizukuri, 1996. Multiple forms of $\beta$-mannanase from Bacillus sp. KK01. Enzyme Microb. Technol., 18: 95-98.

76. Venegas, L.M., A. Téllez, C. Regalado, G. Rodríguez and S. Huerta Ochoa, 1999. Mananasas production for fermentation between solid of agroindustrial waste with filamentous mushrooms. In: Advance in purification and application of enzymes in biotechnology, Prado, A., S. Huerta Ochoa, S. Rodríguez and G. Saucedo (Eds.). Editions UAMI., Mexico, DF., pp: 263-285.

77. Clark, T.A., A.G. Mcdonald, D.J. Senior and P.R. Mayers, 1990. Mannanase and xylanase treatment of softwood chemical puls. In: Advances in Biotechnology in the pulp and paper manufactures: Proceedings from the fourth international conference, Kirk, T.K. and H.M. Chang (Eds.). Butterworhs, Wellington, N.Y, pp: 158-168.

78. Al-Asheh and Duvnjak, 1995. Phytase production and decrease of phytic acid content in canola meal by Aspergillus carbonarius in solid-state fermentation. World J. Microbiol. Biotechnol., 11: 228-231.

79. Ebune, A., S. Al-Asheh and Z. Duvnjak, 1995. Effects of phosphate, surfactants and glucose on phytase production and hydrolysis of phytic acid in canola meal by Aspergillus ficuum during solidstate fermentation. Biores. Technol. 53: 7-12.

80. Coughlan, M.P. and G.P. Hazlewood, 1993. Xylan degrading enzyme systems: Biochemistry, molecular biology and applications. Biotechnol. Applied Biochem., 17: 259-289.
81. Viikari, L., A. Kantelinen, J. Sundquist and M. Linko, 1994. Xylanases in bleaching: From a devises to the industry. FEMS Microbiol. Rev., 13: 335-350.

82. Garg, A., J.C. Roberts and A.J. Mccarthy, 1998. Bleach boosting effect of cellulose-free xylanases of Streptomyces thermoviolaceus and its comparison with two commercial enzyme preparations on birchwood karf pulp. Enzyme Microb. Technol., 27: 594-598.

83. Pellerin, P., M. Gosselin, J.P. Lepoutre, E. Samain and P. Debeire, 1991. Enzymatic production of oligosaccharides from corncob xylan. Enzyme. Microb. Technol., 13: 617-621.

84. Rani, S. and K. Nand, 1996. Development of cellulase-free xylanase-producing anaerobic consortia for the uses of lignocellulolytic wastes. Enzyme. Micrb. Technol., 18: 23-28.

85. Berens S., Kaspari H., Klemme J.H., 1996. Purification and characterization of two different xylanases from thermophilic actinomycete Microtetraspora flexuosa SIIX. Antonie Goes Leeuwenhoek, 69: 235-241.

86. Gerber, P.J., J.A. Heitmann and T.W. Joyce, 1997. Purification and characterization of xylanases from Trichoderma. Biores. Technol., 61: 127-140.

87. Loera, O., J. Aguirre and G. Viniegra-González, 1999. Pectinase production by to diploid construct from two Aspergillus niger overproducing mutants: Isolation, mapping and biochemical characterization. Enzyme. Microbiol. Technol., 25: 103-108.

88. North, M.J., 1982. Comparative biochemistry of the proteinases of eukariotic microorganisms: Microbiol. Rev., 46: 308-340.

89. Rao, M.B., A.M. Tanksale, M.S. Ghatge and V.V. Deshpande, 1998. Molecular and biotechnology aspects of microbial proteases. Microbiol. Molecular Biol. Rev., 62: 597-635.

90. Boyer, P.D., 1971. The Enzymes, 3rd Edn. Academic Press, Inc., New York N.Y.

91. Neurath, H., 1994. The diversity of proteolytic enzymes. In: Proteolytic enzymes a practical approach, Beynon, R.J. and J.S. Bond (Eds.). IRL Press, Oxford, pp: 1-12.

92. Ganesh, K.C. and H. Takagi, 1999. Research review paper: Microbial alkaline proteases: From a bioindustrial viewpoint. Biotechnol. Adv., 17: 561 - 594.

93. Whitaker, J.R., 1994. Principles of Enzymology for the Food Science. Ed. Board. New York, USA, pp: 469-497. 
94. Fox, J.W., J.D. Shannon and J.B. Bjarnason, 1991. Proteinases and their inhibitors in biotechnology. Enzymes in biomass conversion. ACS Symp. Sr., 46: 62-79.

95. Macfarlane, G., S. Macfarlane and G.R. Gibson, 1992. Synthesis and release of proteases by Bacteroides fragilis. Curr. Microbiol., 24: 55-59.

96. Bierbaum, G., 1991. Production of alkaline protease with Bacillus licheniformis in a controlled fed-batch process. Applied Microbiol. Biotechnol., 35: 720 - 724 .

97. Chu, I.M., C. Lee and T.S. Li, 1992. Production and degradation of alkaline proteases in batch cultures of Bacillus subtilis ATCC 14416. Enzyme Microbiol. Technol., 14: 755-761.

98. Gessesse, A. and B. Gashe, 1997. Production of alkaline protease by an alkaliphilic cacteria isolated from an alkaline soda lake. Biotechnol. Lett., 19: 479-481.

99. Lee, Y. and H. Chang, 1990. Production of alkaline protease by Bacillus licheniformis in an aqueous two-phase systems. J. Ferment. Bioeng., 69: 89-92.

100.Umoh, E., 1996. Simultaneous Online Monitoring of Glucose and Total Malto Sugar in Fermentation Processes Using an FIA System J. Chem. Technol. Biotechnol., 67: 276-280.

102.Ramamurthy, V. and R.M. Kothari, 1993. Comparison of fungal protease production by submerged and surface cultivation. J. Biotechnol., 27: $349-354$.

103.Phadatare, S.U., M.C. Sroinivasan and V.V. Desphande, 1993. High activity alkaline protease from Conidiobolus coronatus (NCL 86.8.20): Enzyme production and compatibility with commercial detergents. Enzyme. Microbiol. Technol., 15: 72-76.

104.Boshale S.H., M.B. Rao, V.V. Deshpanade and M.C. Srinivasan, 1995. Thermoestability of high activity alkaline protease from Conidiabolus coronatus (NCL 86.8.20). Enzyme Microbiol. Technol., 17: 136-139.

105.Ottsen, M. and W. Rickert, 1970. The isolation and partial characterization of an acid protease produced by Mucor miehei. Comp. Rend. Trav. Lab. Carlsberg., 37: 301- 325.

106.Ikasari, L.m and D.A. Mitchell, 1994. Protease production by Rhizopus oligosporus in solid-state fermentation. World . J. Microbiol. Biotechnol., 10: 320-324.

107. Malathi, S. and R. Chakraborty, 1991. Production of alkaline protease by a new Asperguillus flavus isolated under solid-substrate fermentation conditions for use as a depilation agent. Applied Environ. Microbiol., 57: 712 -716.
108.Battaglino, R.A., M. Huergo, A.M. Pilosof and G.B. Bartholomai, 1991. Culture requirements for the production of protease by Aspergillus oryzae in solid state fermentation. Applied Microbiol. Biotechnol., 35: 292-296.

109.Fukushima, Y., H. Itoh, T. Fukase and H. Motai, 1989. Continuous protease production in a corbonlimited chemostat culture by salt tolerant Aspergillus oryzae. Applied Microbiol. Biotechnol., 30: 604-608.

110.Fukushima, Y., H. Itoh, T. Fukase and H. Motai, 1991. Stimulation of protease production by Aspergillus oryzae with oils in continuous culture. Applied Microbiol. Biotechnol., 34: 586-590.

111.Tunga, R., R. Banerjee and B.C. Bhattacharyya, 1998. Optimizing some factors affecting protease production under solid state fermentation. Bioprocess Eng., 19: 187-190.

112.Tunga, R., R. Banerjee and B.C. Bhattacharyya, 1999a. Some studies on optimization of extraction process for protease production in SSF. Bioprocess Eng., 20: 485-489.

113.Tunga R., R. Banerjee and B.C. Bhattacharyya, 1999b. Studies of some physical parameters for large scale protease production by SSF. Bioprocess Eng., 21: 187-190.

114.Padmanabhan, S., M.V. Ramana Murthy and B. Lonsane, 1993. Potential of Asperguillus Oryzae CFTRI 1480 for producing proteinase in high titers by solid state fermentation. Applied Microbiol. Biotechnol., 40: 308-340.

115.St. Leguer, R., L. Joshi and D. Roberts, 1994. Adaptation of proteases and carbohydrates of saprophytic and entomopahogenic fungi to the requirements of the ecological niches. Microbiology, 143: 1983-1992.

116.Banerjee, R. and B.C. Bhattacharyya, 1992. Extracellular alkaline protease of a newly isolated Rhizopus oryzae. Biotechnol. Lett., 14: 301-304.

117. Barthomeuf, C., H. Pourrat and A. Pourrat, 1992. Collagenolytic activity of a new semi-alkaline protease from Aspergillus niger. J. Ferment. Bioeng., 73: 233-266.

118.Banerjee, R., R. Agnihotri and B.C. Bhattacharyya, 1993. Purification of alkaline protease of Rhizopus oryzae by foam fractionation. Bioprocess. Eng., 9: 245-248.

119.Fernández Lahore, H.M., M.V. Gallegos Duaigües, O. Cascone and E.R. Fraile, 1997. Solid-state production of a Mucor bacilliformis acid proteases. Rev. Arg. Microbiol., 2: 1-6. 
120.Monod, M., G. Togni, L. Rahalison and E. Frenk, 1991. Isolation and characterization of an extracellular alkaline protease of Aspergillus fumigatus. J. Medical. Microbiol., 35: 23-8.

121.Murakami, K., Y. Ishida, A. Masaki and H. Tatsumi, 1991. Isolation and characterization of the alkaline protease gene of Aspergillus oryzae. Agric. Biol. Chem., 55: 807- 2811.

122.Murthy, M.V.R. and B.K. Lonsane, 1993. Effect of the composition of conidial inoculum development agar media on promoting production of proteinase by Aspergillus oryzae CFTRI 1480 in solid state fermentation system. Chem. Mikrobiol. Technol. Lebensm., 15: 179-184.
123.Ong, P.S. and M. Gaucher, 1976. Production, purification and characterization of thermomycolase, the extracellular serine protease from thermophilic fungus Malbranchea pulchella var. sulfurea. Can. J. Microbiol., 22: 165 -176.

124. Osawa, S., K. Sato and I. Endo, 1996. Repeated batch production of alkaline protease by solidsatate fermentation using urethane foam as carriers. Bioprocess Eng., 14: 63-68.

125.Thakur, M.S., N.G. Karanth and K. Nand, 1990. Production of fungal rennet by Mucor miehei using solid state fermentation. Applied Microbiol. Biotechnol., 32: 409-413. 